\title{
Strategi Pengembangan Desa Pasrujambe Pasca Ditetapkan Sebagai Desa Wisata di Kabupaten Lumajang
}

Albhet Raphow Rudolf Cahyono, ${ }^{\mathrm{a}, 1}$, Nararya Narottamaa, 2

${ }^{1}$ cahyonoalbhet@gmail.com, ${ }^{2}$ nararya.narottama@unud.ac.id

a Program Studi Sarjana Destinasi Pariwisata, Fakultas Pariwisata, Universitas Udayana, Jl. Dr. R. Goris, Denpasar, Bali 80232 Indonesia

\begin{abstract}
Reffering to the regulation of the Lumajang Regent number 79 of 2014 about the spread of tourist destinasion, each sub-distric must has a tourism village. So with this regulation Lumajang has 21 tourism village and one of them is Pasrujambe Village. Pasrujambe Village was designated as a tourism village based on the delibration of all village in Pasrujambe Sub-distric, because the village has potentials of tourism like waterfalls, agriculturan land, grebeg nusantara event etc. But now the tourism potentials has not been maximized for tourism activities, so until now Pasrujambe village has not many tourist. The tourism potentials in the village has the oppotunity to be developed to become a tourist activity like something to do, something to see and something to buy. So to achive this develompent requires a strategies based on the avilable potentials and this reasearch does it. The development srategies fromulated iis expected to have an impact such as increased tourist visits, increased local community pasticipation and optimalization tourism potential in the village. The data used in this research are primary and secondary. In this reseacrh observation, interview and literature studies are used to collect data in the reseach location. Descriptive qualiataif and SWOT analysis were used to analyze the data in this research.This research found that potentials of Pasrujambe Village is devided into three categories namely natural-based, culture-based, and artifical human-based. The strategies were devided into four categories are SO strategy with five strategies formulated, WO strategy with four strategies formulated, ST strategy with four strategies formulated, and WT strategy with three strategies formulate.
\end{abstract}

Keywords: Pasrujambe Tourism Village, Tourism Village, Develompmet Strategy

\section{PENDAHULUAN}

Kabupaten Lumajang secara administratif termasuk pada salah satu bagian dari wilayah Indonesia yang tergabung dalam Provinsi Jawa Timur. Kabupaten ini ikut serta dalam upaya ekspansi atau peningkatan kegiatan kepariwisatan daerah dengan menggunakan keberadaan kapasitas wisata yang telah tersedia di wilayah tersebut. Sebagai wujud nyata ikut serta dalam peningkatan kegiatan pariwisata daerah Kabupaten Lumajang membuat sebuah kebijakan-kebijkan pariwisata yang salah satunya dengan malalui Peraturan Bupati yang dibuat pada tahun 2014 mengenai penyebaran destinasi wisata yang ada di Kabupaten Lumajang, peraturan nomor 79 tersebut mengharuskan setiap kecamatan memiliki satu desa wisata guna mengelaborasi kepariwisataan yang ada dan menyebarluaskan destinasi-destinasi wisata di kabupaten tersebut.

Merujuk pada Peraturan Desa Pasrujambe diutus sebagai salah satu desa wisata yang mewakili wilayah administratif Kecamatan Pasrujambe serta mendapatkan hasil mufakat dari musyawarah yang digelar oleh tujuh desa diantaranya Desa Pasrujambe, Jambekumbu, Sukorejo, Jambearum, Kertosari, Pagowan dan Karangoanom yang berada di wilayah adminisatratif Kecamatan Pasrujambe. Desa ini dirasa cocok menjadi perwakilan desa wisata karena memiliki beragam kapasitas potensi yang bersifat kontributif baik berupa alam, budaya, dan buatan yang layak untuk dikembangkan sebagai tourit atraction, diataranya adanya beberapa air terjun yang memiliki keelokan serta kejernihan airnya dan beberapa kesenian yang autentik guna menjadi tourist attractor seperti keberadaan sanggar musik gamelan jawa serta tradisi grebeg nusantara yang diselenggarakan setiap dua tahun .

Semenjak diputuskan melalui SK Bupati Lumjang menjadi sebuah desa wisata pada tahun 2014, Desa Pasrujambe terus melakukan kegiatan pembenahan dan pembaharuan guna menarik wisatawan untuk melakukan kegiatan wisata di desa tersebut, diantaranya dengan melakukan pembentukan dan penyusunan kelompok sadar wisata serta melakukan penataan aksesbilitas menuju beberapa air terjun yang menjadi daya tarik bagi wisatawan. Namun pembenahan, pembaharuan, dan penataan memang belum diimplemntasikan secara optimal karena adanya beberapa kendala seperti sumber dana yang kurang serta tidak dianggarkan dan sumber daya manusia desa yang belum semua paham akan impact dari adanya tourism activty yang ada didesa, sehingga kapasitas potensi yang tersedia belum mendapat sentuhan pengembangan atau ekspansi secara akurat dan maksimal. Hal ini didukung dari hasil wawancara dengan Haryono selaku Kades Pasrujambe.

Adanya variasi kapasitas potensi yang tersedia di Desa Pasrujambe ini, tentu saja memiliki opportunity ataupun prospek yang mempuni untuk dilakukannya sebuah upaya ekspansi atau pengembangan. Oleh karena itu, peneliti tertarik untuk melakukan pemahaman kapasitas variasi potensi yang ada di Desa Pasrujambe kemudian mencoba merumuskan 
manuver pengembangan yang layak dengan keadaan sebernarnya di desa tersebut.

Hasil dari rumusan strategi tersebut, nantinya dengan mudah dapat diimplentasikan di Desa Pasrujambe. Hal ini nantinya dapat memberikan manfaat ataupun benefit seperti jumlah tourist visit yang betambah dan penambahan income masyarakat sekitar guna meningkatkan taraf kesejahteraan hidup.

Sebagai analisis secara ilmiah dalam penelitian ini terdapat empat konsep yang digunakan terdiri dari: Konsep strategi digunakan untuk merumuskan sebuah rancangan yang terarah bagi Desa Pasrujambe untuk mencapai goals sebagai desa wisata (Chandler, dalam Rangkuti, 2015), Konsep Potensi digunakan sebagai analisis segala kapasitas sumber daya yang sudah ada di Desa Pasrujambe dan berpeluang untuk manuver ekspansi menjadi sebuah kegiatan wisata yang dapat dinikmati oleh wisatawan saat berkunjung (Pendit, 1999), Konsep Desa Wisata digunakan untuk menjabarkan Desa Pasrujambe sebagai sebuah desa wisata yang memiliki keuinakan, orginalitas, dan kelayakan (Arida dan n, 2017), Konsep Pengembangan Pariwisata digunakan sebagai cara atau upaya dalam kegiatan perbaikan, pinigkatan, dan pembaharuan Desa Pasrujambe sebagai desa yang secara resmi memiliki SK sebagai desa wisata (Yoeti, 2008).

Melakukan penelaahan penelitian sebelumnya berguna untuk mengetahui orginalitas pada sebuah penelitian. Pertama, penelitian sebelumnya dilakukan oleh Fitriani (2014) penelitian ini memiliki output untuk merumuskan stretegi pengembangan Desa Wisata Talun dengan basis pemodelan pemberdayaan masyarakat sekitar. Penelitian ini memiliki persamaan yaitu merumuskan atau menciptaka sebuah strategi dengan analisis SWOT namun, pada penelitian sebelumnya merumuskan strategi berbasis peran masyarakat sekitar, sedangkan peneliti merumuskan strategi berbasis variasi kapasitas potensi desa yang dimiliki. Kedua, penelitian oleh Mahagangga (dkk., 2015) tentang desa wisata di kabupaten Badung, provinsi Bali yang dari 11 desa wisata hanya dua desa wisata yang berjalan sesuai harapan. Persamaan penelitian adalah memiliki kesamaan fokus yaitu desa wisata. Perbedaannya adalah metode yang digunakan meskipun kualitatif tetapi tidak menggunakan SWOT.

\section{METODE PENELITIAN}

Lokasi penelitian dan pengambilan data secara umum dilakukan di Desa Pasrujambe, yang merupakan wilayah administratif Kecamatan Pasrujambe, Kabupaten Lumajang. Memiliki jarak 36 $\mathrm{km}$ dari terminal bis Minak Koncar Kabupaten Lumajang. Data Kualitatif yang berupa uraian dan tidak numerik dalam penelitian ini meliputi; gambaran umum mengenai keberadaan Desa Pasrujambe, variasi kapasitas potensi Desa Pasrujambe, dan startegi pengembangan Desa
Pasrujambe yang dirumuskan atau diciptakan berdasarkan kondisi eksisting peluang, ancaman, kekuatan dan kelemahan yang dihadapi desa tersebut. Data Kuantitatif yang dapat diukur dengan angka pada penelitian ini adalah data mengenai luas wilayah Desa Pasrujambe dan jumlah dusun. Data primer dan sekunder merupakan sumber data yang digunakan dalam penulisan penelitian ini. Data primer yang diperoleh langsung dari lokasi meliputi gambaran umum mengenai kondisi Desa Pasrujambe, variasi kapasitas potensi Desa Pasrujambe dan strategi pengembangan yang dirumuskan atau diciptakan mengetahui dan menelaah kondisi sebenarnya mengenai peluang, ancaman, kekuatan dan kelemahan yang dihadapi Desa Pasrujambe. Sedangkan, data skunder pada penelitian ini diperoleh dari buku monografi Desa Pasrujambe yang didapat dari sekertariatan pemerintah desa mengenai kondisi geografis dan topografis wilayah.

Purposive sampling merupakan teknik penentuan infroman yang diterapkan pada penelitian (Koenjaraningrat, 1997). Para informan yang dipilih untuk memberikan infromasi tidak kurang harus memiliki kemampuan dan wawasan terhadap lokasi penelitain sehingga mampu untuk memberikan data yang sesuai dengan permasalahan penelitian di lokasi tersebut. Adapun informan yang dianggap memenuhi kriteria tersebut adalah Hariono (Kades Pasrujambe), Catur (Ketua Pokdarwis Desa Pasrujambe) dan Atim (Kadus Pasrujambe). Selanjutnya data yang diperlukan dalam penelitian ini dikumpulkan dengan menerapkan teknik observasi (Suryawan, dkk., 2017). Pengamtan langsung di Desa Pasrujambe mengenai kondisi gamabaran Desa Pasrujambe secara umum, variasi kapasitas potensi yang sudah ada di Desa Pasrujambe dan kondisi eksisting mengenai kelemahan, kekuatan, ancaman dan peluang yang dihadapi Desa Pasrujambe nantinya memiliki fungsi sebagai landasan untuk merumuskan atau menciptan rancangan sistematis atau disebut strategi pengembangan sebagai desa wisata, data-data tersebut juga dikumpulkan dengan menggunakan teknik indepth interview atau sering dikenal wawancara mendalam terhadap informan yang telah ditentukan (Koenjaraningrat, 1997). Sedangkan data pendukung mengenai Desa Pasrujambe dikumpulkan melalui teknik studi kepustakaan yaitu buku monografi Desa Pasrujambe.

Data yang sudah terkumpul selajutnya dianalisis dengan teknik analisis deskriptif kualitatif menggunakan SWOT (Rangkuti, 2015). Berdasarkan data-data tersebut diupayakan merumuskan atau menciptakan sebuah strategi- stratefgi pengembangan di Desa Pasrujambe yang lebih optimal, tepat, dan terarah.

\section{HASIL DAN PEMBAHASAN}

\section{A. Gambaran Umum Desa Pasrujambe}


Ekpansi dan penyebaran destinasi wisata disetiap Kecamatan di Kabupaten Lumajang diwujudkan melalui Peraturan Bupati Nomor 79 Tahun 2014, yang telah merujuk Desa Pasrujambe sebagai salah satu desa wisata berdasarkan SK Bupati dan hasil musyarawah enam desa yang ada di wilayah administratif Kecamatan Pasrujambe karena dinilai mempunyai kapasitas variasi potensi yang layak untuk di lakukan kegiatan ekspansi dan dijadikan perwakilan desa wisata di kecamatan tersebut.

Desa Pasrujambe memiliki luas wilayah 10.066 hektare, dengan 11 dusun yang tersebar. Masingmasing dusun memeiliki potensinya tersendiri seperti: Dusun Tulungrejo, Dusun Plambang dan Dusun Tawonsongo penduduk mayoritas sebagai petani, hasil pertanian paling banyak adalah pisang, Dusun Ngampo, Dusun Sumberingin, Dusun Suco dan Dusun Jabon mayoritas penduduk juga sebagai petani dengan sektor pertanian kopi dan pisang, Dusun Munggir mayoritas penduduk sebagai petani padi, Dusun Krajan I dan Dusn Krajan II mayoritas penduduk sebagai petani ubi jalar namun ada sebagaian penduduk yang berkerja sebagai buruh tambang pasir. Setiap dusun di Desa Pasrujambe memang mempunyai variasi potensi yang berbedabeda pula, namun kebayakan penduduk berkecimpung sebagai pekerja sektor pertanian baik itu padi, pisang, kopi,dan ubi jalar. Jumlah penduduk yang tersebar di 11 dusun Desa Pasrujambe sebesar 13.686 jiwa. Keadaan topografis desa ini termasuk dalam dataran tinggi yang ketingginy mencapai 650 mdpl dengan kondisi cuaca tergolong pada iklim basah dengan kondisi intesitas curah hujan yang tinggi dan memiliki suhu rata-rata harian tertinggi maksimum 27 derajat celcius.

Setelah diputusakan oleh SK Bupati Lumajang sebagai desa wisata tahun 2014 aktivitas pariwisata di Desa Pasrujambe tergolong pada low activity of tourism. Dimana aktivitas wisatawan tidak begitu terlihat di desa ini. Catur sebagai ketua pokdarwis menjelaskan bahwa memang aktivitas wisatawan cenderung tidak ada, fenomena tersebut sesuai dengan data jumlah kunjungan wisatawan yang masih sedikit. Hal ini disebabkan memang belum ada upaya yang serius untuk mengoptimalkan potensipotensi yang ada dan memang terkendala oleh anggaran dana yang tersedia.

\section{B. Potensi Desa Pasrujambe}

\section{Potensi Berbasis Alam}

Potensi berbasis alam merupakan segala sumber daya yang terdapat pada lingkungan alam dan sudah tersedia.

\section{a. Tiga Air Terjun}

Memiliki ketinggian 650 mdpl (meter diatas permukaan laut) menjadikan letak posisi desa berada di dataran tinggi. Hal ini menjadi salah satu faktor penyokong bagi Desa Pasrujambe memiliki beberapa air terjun dengan tebing-tebing cukup tinggi, sehingga panorama yang disuguhkan mempunyai keelokan alam yang tercipta dari aliran air jatuh dari atas ketinggian tebing. Ketegia Air Terjun yang dimiliki Desa Pasrujambe tersebar di dusun yang berbeda diantaranya: Dusun Ngampo sebagai lokasi air terjun Kedung Guwo, Dusun Tawonsongo sebagai lokasi air terjun Watu Lapis dan Dusun Suci sebagai lokasi air terjun Kedung Kuwung.

Berdasarkan keterangan Catur Sebagai Ketua Pokdarwis setempat menyatakan bahawa saat ini dari ketiga air terjun tersebut yang menjadi prioritas oleh Pokdarwis untuk kegiatan ekspansi adalah air terjun Watu Lapis yang berlokasi di Dusun Tawonsongo. Air terjun ini mendapat pengelolaan secara utuh oleh pokdarwis Desa Pasrujambe. Hal ini dikarenakan air terjun ini lebih dulu dikenal oleh wisatawan dan memiliki ketinggian tebing yang melebihi dari kedua air terjun lainnya yang membuat panorama kelokan air jatuh dari tebing lebih menakjubkan. Sementara Air Terjun Kedung Guwo dan Air Terjun Kedung Kuwung yang berlokasi di Dusun Ngampo dan Dusun Suco belum dikelola secara maksimal oleh Pokdarwis maupun desat setempat karena memiliki kunjungan wisatawan yang cenderung sedikit dan hampir tidak ada.

Ketiga air terjun tersebut masih memiliki lingkungan yang begitu asri karena dikeliling oleh berbagai keberagaman jenis flora yang tumbuh dan hidup di area air terjun tersebut. Keberadaan ketiga air terjun ini berpotensi untuk dilakukan ekspansi untuk dijadi sebagai atraksi yang dapat dinikmati wisatawan ketika berkunjung ke Desa Wisata Pasrujambe.

\section{b. Lahan Pertanian}

Berdasarkan buku profil desa sebagain masyarakat Desa Pasrujambe memang menekuni profesi sebagai petani dan buruh tani. Dusun Ngampo ialah salah satu dari 11 dusun yang menjadi wilayah strategis dalam sektor pertanian terutama hasil tani berupa padi. Selain padi masyarakat juga menghasilkan beberapa hasil pertanian seperti ubi jalar, pisang dan berbagai rempah rempah. Budidaya ubi jalar sebagian besar terletak di Dusun Suco dan Dusun Krajan I, sebagaian masyarakat di dusun ini bermata pecaharian sebagai petani ubi jalar, jenis ubi yang dibudidaya oleh petani merupakan jenis ubi ungu dan ubi kuning dimana ubi jenis ini memiliki tingkat kemanisan yang cukup tinggi. Selanjutnya hasil bumi berupa pisang sangat hidup subur di Dusun Tulungrejo, Plambang dan Tawonsongo, sebagian masyarakat didusun ini menjadikan pisang sebagai produk pertanian yang ditanam dikebun ataupun pekarangan rumah, jenis pisang yang mereka tanam sebagian besar pisang agung yaitu jenis pisang yang menjadi ikon Kabupaten Lumajang. Kemudian, rempah-rempah berupa jahe, kunyit, temulawak dan kecur mudah ditemukan di Dusun 
Suco. Masayarakat di dusun ini menjadikan rempah sebagai jamu-jamu tradisional yang dikemas dalam botol dan dijual langsung kepasar sebagai bumbu dapur.

Aktivitas pertanian yang menjadi profesi sebagaian besar masyarakat Desa Pasrujambe dapat menjadi sebuah peluang yang dapay dioptimalkan secara terarah sebagai sebuah atraksi wisata yang dapat dinikmati. Melihat hakikat dari desa wisata yang menjual orginalitas atau keunikan yang tersedia di desa tersebut, aktivitas pertanian sangat cocok, karena kegiatan ini merupakan sebuah kegiatan yang asli dilakukan dalam kesehariannya oleh masyarakat tanpa dibuat-buat. Kegiatan ini dapat diciptakan untuk menambah benefit bagi para petani untuk memaksimalkan usaha atau kegiatan yang mereka lakukan sehari-hari yaitu bertani.

\section{c. Budidaya Kopi Robusta}

Memiliki suhu rata rata maksimal 26 derajat celcius menjadikan Desa Pasrujambe cocok untuk budidaya tanaman kopi. Kopi robusta menjadi komoditi yang dihasilnya oleh beberapa petani yang tersebar dibeberapa dusun yang ada di Desa Pasrujambe. Jenis kopi robusta dipilih oleh para petani karena aspek pemasaran yang dirasa cukup mudah, kopi ini hampir memiliki peminat yang cukup besar. Biasanya petani menjual hasil kopi berupa bijian kopi yang siap diolah maupun olahan jenis kopi yang sudah disangrai dan siap seduh.

Beberapa dusun sebagai penghasil kopi robusta antara lain Dusun Tulungrejo, Plambang dan Tawonsongo, dimana dusun-dusun ini memiliki pohon kopi yang cukup banyak dan dapat dikatakan sebagai dusun dengan hamparan perkebunan kopi yang luas. Kegiatan petani kopi ketiga dusun tersebut tentu saja dapat dioptimalkan dan dimaksimalkan keberadaannya menjadi sebuah atraksi wisata yang dapat memeperlihatan atau menyuguhkan kegiatan petani dimulai dari kegiatan penaman bibit hingga memanen biji kopi. Pengoptimalan hasil panen kopi juga bermanfaat sebagai produk something to buy bagi wisatawan yang berkunjung di Desa Pasrujambe.

\section{Potensi Berbasis Budaya}

Potensi berbasis budaya yang dimaksud adalah segala sesuatu cipta, rasa dan karsa masyarakat Desa Pasrujamnbe baik berupa kesenian ataupun adat istiadat yang tersedia. Beberapa potensi berbasis budaya yang ada di Desa Pasrujambe sebagai berikut: a. Kesenian Karawitan Gamelan Jawa

Kesenian karawitan merupakan kesenian yang tersebar di Pulau Jawa. Kesenian yang terdiri dari beberapa alunan gamelan yang dimainkan untuk menghasilkan nada-nada yang selaras dan enak untuk dipedengarkan. Mbah Cuwo sebagai salah satu tokoh masyarakat Desa Pasrujambe sekaligus leader and fouder sanggar budaya Wahyu Budoyo merupakan sosok yang masih mempertahankan keberadaan kesenian karawitan terutama yang ada di Desa Pasrujambe. Beliau mempersilahakan sanggarnya bagi karangtaruna yang ingin belajar kesenian ini, bahkan beliau juga menerima orang-orang umum untuk berlatihan kesenian karawitan tersebut dengan maksud agar kesenian ini tetap terjaga dan lestari.

Kegiatan yang dilakukan Mbah Cuwo ini tentu dapat dioptimalkan menjadi sebagai something to do yang dapat dilakukan wisatawan saat berkunjung ke Desa Pasrujambe. Selain itu, kegitan something to se juga dapat dilakukan wisatawan dengan menggelar pertujunkan kesenian karawitan secara berkala dan terjadwal. Hal ini tentu juga dapat memberikan dampak yang positf bagi pelestarian budaya kesenian karawitan di Desa Pasrujambe, dengan banyakanya wisatawan yang ingin belajar dan melihat serta mendengar alunan gamelan tersebut, secara tidak langsung eksistesi kesenian gamelan dan sanggar budaya agar tetap terjaga.

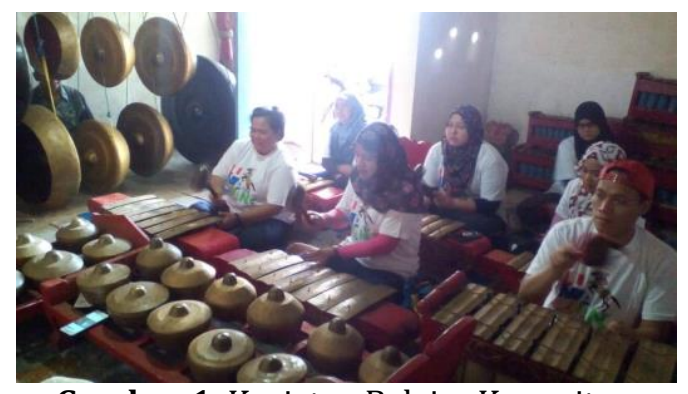

Gambar 1. Kegiatan Belajar Karawitan Sumber: Catur (Ketua Pokdarwis Pasrujambe), 2018

b. Area Air Suci Watu Klosost

Air Suci Watu Klosost dipercaya masyarakat Desa Pasrujambe sebagai area suci yang mampu memberikan keamanan dan kesejahteraan desanya. Area suci ini berdasarkan asal muasalnya dan ceita masyarakat sekitar merupakan tempat suci yang digunakan untuk bersemedi atau bertapa bagi seseorang guna mendekatkan diri kepada sang pencipta. Air suci yang dihasilnya dari area ini dipercaya mampu memberikan bebrapa khasiat awet muda bagi yang meminum dan menggunakan air tersebut untuk membasuh muka.

Sebagai area yang memiliki asal-usul dengan sejarah tersebarnya Agama Hindhu di Lumajang dan ada keterkaitannya dengan gunung tertinggi pulau jawa yaitu Gunung Mahameru/Semeru serta keterkaitan dengan Pura Suci Madaragiri Semeru, menjadikan area Watu Klosot ini dapat dioptimalkan dan dimaksimalkan secara tepat sebagai something to do bagi wisatawan yang ingin berdoa maupun sekedar membasuh muka mengunakan air suci yang ada, telebih cerita akan kegunaan dan manfaat dari air suci tersebut.

\section{c. Kesenian Jaran Kencak}

Kabupaten Lumajang selain dikenal memiliki ikon sebagai Kota Pisang juga terkenal dengan ikon 
kesenian jaran kencak. Jaran kencak senderi memiliki arti kuda yang bergoyang. Jaran kencak dipercaya ada semenjak Kerajaan Lamajang Tigang Juru terbukti dengan ditemukannya relief batu batu yang mirip dengan bentuk kuda menari di Kecamatan Kunir bagian dari wilayah Kabupaten Lumajang. Relief tersebut dipercaya sebagai penginggalan dari Kerajaan Lamajang Tigang Juru sebuah kerajaan yang dipimpin oleh Arya Wiraraja dan sempat berjaya di kabupaten ini.

Hampir setiap wilayah kecamatan di Kabupaten Lumajang memiliki dan melestarikan kesenian ini, tidak terkecuali kecamatan Pasrujambe. Oleh sebab itu, sebagian karangtaruna Desa Pasrujambe juga ikut melestarikan kesenian jaran kencak ini. Karangtaruna tersebut biasanya berperan sebagai penari, pengendali kuda, dan penambuh musik dalam setiap pagelarannya. Sebagi upaya melestarikan kesenian ini hampir setiap tahun masyarakat jika memiliki acara hajatan akan mengadakan pertunjukan pagelaran ini, sebagai simbol status sosial bagi masyarakat yang menggelar pertujukan jaran kencak tersebut serta memperkenalkan kesenian ini pada generasi muda.

Sebagai kesenian khas Kabupaten Lumajang dan mendapat simpati dan empati dari karangtaruna Desa Pasrujambe tentunya kesenian ini dapat dioptimalisasi menjadi sebuah pagelaran yang dapat diagendakan untuk kegiatan something to see atapun something to learn wisatawan yang berkunjung ke Desa Pasrujambe.

\section{Potensi Berbasis Buatan}

Potensi buatan yang dimaksud adalah segala sesuatu yang sengaja diselenggarakan oleh sumber daya manusia Desa Pasrujambe dengan memanfaatkan kondisi alam dan budaya. Adapun potensi buatan di Desa Pasrujambe sebagai berikut:

a) Kirab Grebeg Nusatara

Desa Pasrujambe merupakan desa yang memiliki hasil tani yang melimpah berupa padi, pisang, sayuran, ubi jalar dan kopi setiap tahunnya. Rasa syukur kepada sang pemberi rezeki tentu harus ucapkan dan diapresiasikan. Peduduk Desa Pasrujambe mengapresiasikan rasa syukur tersebut dengan menggelar acara tasyakuran yang berupa Kirab Grebeg Nusantara dan diselenggarakan sekali dalam dua tahun.

Acara Kirab Grebeg Nusantara ini biasanya diawali dengan arak-arakan hasil tani yang disusun secara menggunung dan meinggi untuk menyimbolkan hasil panen yang melimpah dan mencapai langit, kemudian adanya penampilan kesenian tradisional seperti tari-tarian, seni karawiitan dan seni jaran kencak yang dipersembakan dari karangtaruna dan masyarakat umum, kemudian berakhir dengan acara pengajian akbar yang dihadiri oleh beberapa Kyai dan Ulama untuk memanjatkan doa syukur atas rasa aman, nyaman dan hasil tani yang melimpah bagi penduduk Desa Pasrujambe dari Tuhan Yang Mahaesa.

Sebagai acara rutin yang diselenggarakan penduduk Desa Pasrujambe, Kirab Grebeg Nusantara ini dapat dicantumkan pada kalender pariwisata Desa Pasrujambe. Sehingga nantinya wisatawan dapat berkunjung pada saat acara kirab diselenggarakan. Kirab ini akan menjadi menarik bagi wisatawan karena menampilkan keoriginalitasan dan autentik penduduk dalam menyampaikan rasa syukur kepada Sang Maha Pencipta.

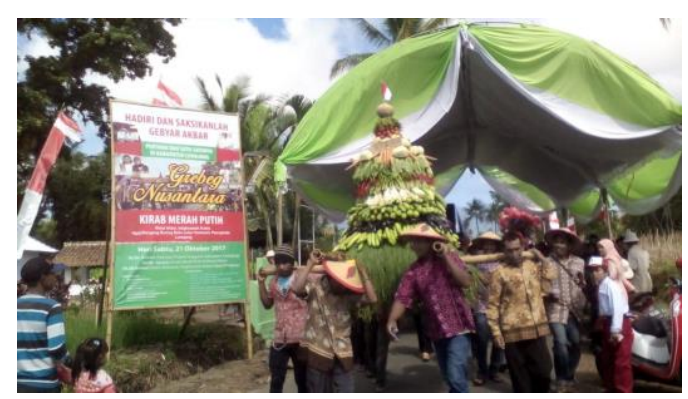

Gambar 2. Rangkaian Acara Kirab Grebeg Nusatara Sumber: Catur (Ketua Pokdarwis Pasrujambe), 2018

b) Olahan Hasil Pertanian

Penduduk Desa Pasrujambe mayoritas berkerja sebagai petani dan buruh tani, menjadikan hasil pertanian di desa ini cukup melimpah. Hasil pertanian tersebut berupa padi, pisang, kopi, singkong dan ubi jalar serta rempah-rempah. Hal ini mendorong ide-ide kreatif yang muncul untuk mengolah hasil pertanian tersebut untuk nilai ekonomi yang lebih tinggi. Berdasarkan buku profil Desa Pasrujambe tahun 2019 terdapat tiga sampai empat usaha kecil menengah (ukm) yang mengelola hasil pertanian tersebut, khususnya hasil olahan pisang dan umbi-umbian yang diolah menjadi kripik dengan rasa yang beragam. Adapun usaha kecil menengah tersebut tersebar di berbagai dusun di Desa Pasrujambe antara lain Dusun Plambang, Ngampo, Munggir dan Pasrepan.

Produk olahan hasil pertanian yang dihasilkan oleh penduduk Desa Pasrujambe ini tentu dapat dijadikan sebagai jajanan khas dan buah tangan yang dapat dibeli wisatawan saat berkunjung ke Desa Pasrujambe. Kegiatan something to buy dapat dilakukan wisatawan dengan membeli produk olahan pertanian yang dihasilkan oleh penduduk Desa Pasrujambe, selain dapat memberikan produk kepada wisatawan juga memberikan keuntungan bagi para Umk.

\section{Identifikasi Peluang, Ancaman, Kekuatan dan Kelemahan di Desa Pasrujambe.}

Kondisi peluang, ancaman, kekuatan dan kelemahan akan diidentifikasi secara tepat sesuai dengan kondisi yang dihadapi Desa Pasrujambe. Adapun identifikasinya sebagai berikut: 


\section{Peluang (Opportunities) Desa Pasrujambe}

Keadaan Desa Pasrujambe yang menjadi sebuah peluang untuk penngembangan desa wisata adalah sebagai berikut:

a. Kabupaten Lumajang sebagai salah satu daerah yang mulai memeperhatikan keberadaan sektor pariwisata yang tersebar dilingkup wilayahnya. Hal ini terbukti dengan adanya 21 desa wisata yang diutus termasuk Desa Pasrujambe tahun 2014 guna meningkatan sebaran destinasi wisata di Kabupaten Lumajang. Sehingga dapat dikatakan bahwa atensi pemerintah terhadap desa-desa wisata cukup tinggi dengan tujuan desa wisata tersebut akan berkembang dan menjadi daya tarik wisata baru di Kabupaten Lumajang.

b. Mempunyai SK Bupati Lumajang sebagai desa wisata, sehingga memiliki dukungan sepenuhnya dari dinas terkait dengan kepariwisataan terutama dari Disparbud (Dinas Pariwisata dan Kebudayaan) Kabupaten Lumajang dan dari berbagai intasu pemerintah yang mendukung kegiatan pariwisata yang diselenggarakan di Desa Pasrujambe.

c. Kondisi sarana akses menuju Desa Pasrujambe yang sudah mendukung untuk dilakukannya mobilitas oleh wisatawan karena keberadaan kondisi jalan dan petunjuk arah sudah cukup baik. Selain itu posisi Desa Pasrujambe yang cukup strategis kareba memiliki kedekatan lokasi dengan Hutan Bambu Sumbermujur dan B29, dimana daya tarik wisata tersebut sudah memiliki atensi dari kalangan wisatawan.

\section{Ancaman (Treaths) Desa Pasrujambe}

Keadaan Desa Pasrujambe yang dapat dikategorikan sebagai ancaman adalah sebagai berikut:

a. Berdasarkan surat Peraturan Bupati yang beredar, setidaknya ada SK Bupati Lumajang mengenai 21 desa wisata yang diterbitkan di Kabupaten Lumajang. Dengan kata lain ada 21 desa wisata yang secara bersamaan melakukan upaya-upaya ekspansi dengan basic potensi yang sama dengan mengutamakan alam dan budaya, sehingga memunculkan persaingan yang ketat untuk menarik kunjungan wisatawan. b. Kabupaten Lumajang terkenal akan maraknya fenomena kriminalitas begal, penodongan, dan jambret yang sangat keji melukai korbannya. Hal ini menjadi momok bagi wisatawan, sehingga wisatawan biasanya enggan untuk berkunjung ke daya tarik wisata yang jauh dari pusat kota karena rasa takut mereka terhadap wilayah yang cenderung sepi seperti pedesaan, dengan kata lain citra Kabupaten Lumajang terhadap fenomena tindak kriminatlitas begal dan sejenisnya masih kurang baik terlebih pada lokasi yang cenderung sepi dan diarea pedesaan.

c. Terletak di dataran tinggi dan berada di wilayah lereng gunung yang masih aktif yaitu Gunung Semeru, menjadikan bencana alam sebagai fenomena yang mengancam dan dapat datang kapan saja. Bencana alam yang diperdiksikan dapat terjadi berdasarkan kondisi geograsi dan topografis lingkungan sekitar Desa Pasrujambe antara lain tanah longsor, luapan lahar dingin, gunung meletus dan wedus gembel. Hal ini tentu menjadi sebuah warning bagi wisatawan yang ingin berkunjung.

\section{Kekuatan (Strengths) Desa Pasrujambe}

Kondisi Desa Pasrujambe yang menjadi kekuatan adalah sebgai berikut:

a. Desa Pasrujambe memiliki kapasitas variasi potensi yang cukup menarik sebagai produk wisata unggulan antara lain tiga air terjun, kesenian karawitan dan jaran kencak, kirab grebeg nusantara, area air suci watu klosot, lahan pertanian serta hasil olahan petanian. Keberadaan variasi potensi yang memiliki originalitas tersebut berpotensial untuk dilakukannya atau diciptakannya program yang merujuk pada kegiatan optimalisasi secara tepat dan terarah sebagai produk atraksi wisata yang dapat mendukung keberadaan Desa Wisata Pasrujambe.

b. Potensi-potensi wisata yang terdapat di Desa Pasrujambe memiliki originalitas dan keunikan sangat tinggi, karena potensi tersebut berhubungan erat dengan kegiatan keseharian masayarakat setempat tanpa dibuat-buat, sehingga kelestarian dan keberadaan potensi tersebut akan terus ada dan berkelanjutan. 
c. Keberadaan potensi alam dan budaya di Desa Pasrujambe memiliki power tersediri sehingga dapat menciptkan variasi potensi buatan lainnya yang memiliki hubungan erat dengan potensi alam dan budaya tersebut. Contohnya kegiatan kirab grebeg nusatara dan olahan hasil pertanian tentunya dengan memanfaatkan hasil lahan pertanian dan kesenian-kesenian yang dimiliki masyarakat Desa Pasrujambe.

\section{Kelemahan (Weakness) Desa Pasrujambe}

Kondisi Desa Pasrujambe yang menjadi kelemahan adalah sebagai berikut:

a. Sebagian besar sumber daya manusia Desa Pasrujambe belum secara maksimal memiliki pengetahuan umum maupun khusu dalam bidang kepariwisataan, tetapi adapula bebrapa masyarakat yang sudah terjun dalam kegiatan pariwisata sebelumnya. Hal ini menyebabkan dalam pengelolaan sebagai desa wisata belum dilakukan secara optimal dan terarah oleh Pokdarwis Desa Pasrujambe dan masyarakatnya.

b. Fasilitas pendukung pariwisata merupakan sebuah kebutuhan pokok yang harus dimiliki untuk melaksanakan kegiatan pariwisata, Desa Pasrujambe sendiri saat ini masih tergolong sebagai desa wisata yang sangat minim akan fasilitas pendukung wisata (amenitas) seperti tidak adanya pusat infromasi pariwisata ataupun brosur mengenai produk wisata yang ada di Desa Pasrujambe.

c. Sebagai desa wisata tidak menganggarkan dana khusus dan memiliki sumber dana yang bisa dialokasikan, sehingga menghambat kegiatan yang berkaitan dengan ekspansi, peningkatan, dan pengelolaan kegiatan kepariwisataan di desa. Hal ini berdampak pada pemenuhan dan pengadaan fasilitas wisata yang sangat lamban dan kegiatan promosi yang kurang maksimal.

d. Atensi masyarakat Desa Pasrujambe masih tergolong sangat lemah. Hal ini disebabkan masyarakat belum memiliki wawasan secara menyeluruh tentang keberadaan variasi potensi wisata yang tersedia dan yang dapat dioptimalkan serta minimnya pengetahuan akan benefit yang didapatkan dalam menjalankan kegiatan pariwisata di desanya.
Hal ini tentu menyebabkan tingkat paritisipasi masyarakat Desa Pasrujambe dalam kegiatan pariwisata cenderung masih kurang.

\section{Strategi Pengembangan Potensi Desa Wisata Pasrujambe}

Hasil dilakukanya identifikasi matriks SWOT di Desa Pasrujambe, maka dapat dirumusakan beberapa startegi untuk mengembangkan Desa Pasrujambe sebagai desa wisata yang teapat dan lebih terarah. Adapun strategi-startegi sebaga berikut:

\section{Strategi SO (strengths - opportunities)}

Adapun startegi-stategi yang dapat dirumuskan untuk Desa Pasrujambe dengan memaksimalkan kekuatan dan peluang yang ada, sebagai berikut:

a. Menetapkan beberapa potensi yang ada di Desa Pasrujambe sebagai aktivitas wisatawan seperti: 1) Potensi berbasis alam berupa Air Terjun Watu Lapis dan aktivitas lahan pertanian sebagai produk something to do serta something to see bagi wisatawan yang menyukai wisata berbasis alam. Hal ini dilakukan dengan cara mempersiapkan sarana aksesbilitas dengan mengadakan perbaikan jalan ataupun penambahan petunjuk jalan menuju air terjun tersebut. Selain itu kualitas amenitas yang perlu ditingkatkan pada lokasi ketiga air terjun tersebut, karena kenyamanan wisatawan dapat diukur dengan keberadaan dan kelengkapan amenitas yang medukung di sebuah daya tarik wisata. 2) Potensi berbasis budaya berupa Kesenian Jaran Kencak dan Kesenian Karawitan Gamelan Jawa sebagai something to see dan something to learn bagi wisatawan dengan mengatur agenda pagelaran kedua kesenian tersebut yang nantinya dapat mengundang perhatian wisatawan untuk berkunjung. Selain itu kedua kesenian tersebut juga dapat sebagai aktivitas something to do bagi wisatawan untuk belajar menari dan mengendalikan Jaran Kencak atau dapat juga berlatih memainkan keselarasan nada gamelan.

b. Pembuatan paket wisata Desa Pasrujambe yang dapat menjadi pilihan wisatawan saat akan berkunjung. Paket wisata dapat berupa paket wisata tani dengan menjual variasi potensi berbasi alam seperti area petanian, olahan hasil pertanian dan air terjun yang tersedia di Desa Pasrujambe. Selain itu, paket wisata berbasis budaya yang ada di Desa Pasrujambe juga dapat dibuat dengan mengoptimalkan kesenian Karawitan Gamelan Jawa dan kesenian Jaran Kencak melalui pagelaran petunjukan ataupun pelatiahan dengan membuka kelas belajar bagi wisatawan. Pembuatan paket wisata dinilai perlu karena setiap wisatawan memiliki tipologi yang berbeda-beda seperti wisatawan yang menyukai lingkungan atau alam 
adapula wisatawan yang menyukai kebudayaan masyarakat lokal.

c. Menggandeng pihak daya tarik wisata lain yang memiliki lokasi tidak jauh dari Desa Pasrujambe seperti Pura Mandara Giri Semeru Agung, B29 dan Hutan Bambu Sumbermujur untuk saling mendukung kegiatan pariwisata dengan cara saling menempelkan pamflet profil keberadaan kegiatan aktivitas wisata, Hal ini dilakukan agar wisatawan yang berkunjung dapat mengatahui variasi potensi masing-masing daya tarik wisata.

d. Mengikuti beberapa tourism events untuk mengenalkan kapasitas variasi potensi desa baik yang diselenggarakan oleh pemerintah daerah ataupun pihak swasta lainnya. Keikutsertaan atau partisiapasi dalam sebuah tourism events dinilai sangat penting karena selain dapat mengenalkan variasi potensi wisata yang ada juga dapat menambah eksistensi Desa Pasrujambe sebagai salah satu desa wisata di Kabupaten Lumajang, sehingga nantinya berdampak pada popularitas dan dapat dikenal masyarakat luas.

e. Menyusun perencanaan dalam bentuk proposal pengembangan Desa Pasrujambe guna menarik pihak swasta (investor) untuk bekerja sama mengembangkan dan mengeksplor variasi potensi wisata yang ada dan penambahan dan peningkatan keberadaan amenitas pariwisata guna mendukung aktivitas wisata bagi wisatawan. Hubungan kerja sama dengan pihak swasta (investor) sangat perlu dilakukan mengingat Desa Pasrujambe kekurang dalam hal anggran pengembangan desa wisata. Hal ini dapat dengan mudah dilakukan terlebih Desa Pasrujambe sudah resmi mempunyai SK legalitas sebagai desa wisata yang diputuskan oleh Pemerintah Kabupaten Lumajang.

\section{Strategi WO (weakneess - opportunities)}

Strategi-startegi yang dapat dirumuskan untuk Desa Pasrujambe dengan meminimalisir kelamahan dan memaksimalkan peluang adalah sebagai berikut:

a. Menjalin koordinasi dan komunikasi secara berkala dengan pemerintah daerah khususnya instansi DISPARBUD (Dinas Pariwisata dan Kebudayaan) Kabupaten Lumajang dengan baik guna mendapatkan fasilitas penyuluhan atau pelatihan pengetahuan umum dan khusus kepariwisataan bagi masyarakat lokal. Hal ini perlu dilakukan agar menumbuhkan sikap memiliki dan untuk memompa atensi asyarakat dalam menjalankan aktivitas kepariwisataa di Desa Pasrujambe, dimana dapat diketahui bahwa saat ini atensi masyarakat masih tergolong rendah untuk kegiatan wisata di desanya. Bekerjasama menjalin komunikasi dan hubungan baik dengan pemerintah Kabupaten Lumajang terutama intansi terkait dengan kepariwisataan sangat mutlak perlu dilakukan, karena pemerintah berperan sebagai fasilitator untuk memfasilitasi dan regulator pembuatan kebijakan berkaitan dengan kepariwisataan di Kabupaten Lumajang.

b. Berkolaborasi dengan instansi pendidikan seperti perguruan tinggi dibidang kepariwisataan untuk perencanaan dan ekpansi sebagai desa wisata dengan mengoptimalkan berbagai variasi potensi yang sudah ada. Selain itu civitas akademika perguruan tinggi dapat pula melakukan kegiatan pengabdian masyarakat didesa untuk kegiatankegiatan pariwisata seperti bina desa ataupun kegiatan lainnya. Hal ini perlu dilakukan agar masyarakat dapat diberikan knowladge dan skill untuk menyajikan sikap hospitality yang layak kepada wisatawan saat berkunjung. Mengingat mayoritas masyarakat lokal yang menggelutin profesi sebagai petani, sehingga kurang akan pengetahuan dan skill perihal kegiatan pariwisata.

c. Mengajukan ataupun merencanakan anggaran dana yang diajukan kepada pemerintah daerah setempat ataupun pihak swasta guna melakukan perbaikan, peningkatan, dan pengadaan fasilitasfasilitas yang mendukung aktivitas kepariwisataan. fasilitas tersebut dapat berupa papan informasi pariwisata, peta persebaran atrkasi wisata, toilet bagi wisatawan, penunjuk jalan menuju lokasi atraksi wisata, rest area, tempat sampah, pertokoan kebutuhan wisatawan, dan homestay. Hal ini menjadi sangat penting karena kenyamanan dan kepuasan wisatawan dapat diukur dengan jumlah dan ketersediaan amenitas yang dapat dirasakan wisatawan di Desa Pasrujambe.

d. Meningkatkan dan optimalisasi pengadaan sarana advertensi bagi Desa Pasrujambe untuk memperkenalkan segala variasi potensi yang tersedia. Dimana kegiatan advertensi atau pengiklanan perlu dilakukan untuk menyebar luaskan kegiatan pariwisata yang tersedia di Desa Pasrujambe. Sarana advertensi dapat dilakukan dengan secara online ataupun offline. Secara online Pokdarwis dapat menggunakan media sosial seperti website, facebook, twitter, dan instagram dengan membuat official account untuk mempromosiakan beberapa paket wisata yang ada dan menampilkan keberadaan variasi potensi alam, budaya, dan buatan yang dimiliki serta menampilan beberapa kegiatan wisata yang dapat dilakukan di desa tersebut. Media promosi offline dapat berupa brosur atau pamflet paket wisata yang disebar luaskan melalui agent-agent tour and travel di Kabupaten Lumajang dan sekitarnya. Promosi juga dapat dilakukan dengan menjalin hubungan kerja dengan agent tour and travel untuk mencantumkan Desa Pasrujambe sebagai salah satu list tour agent tersebut untuk dikunjungi. Kerjasama dengan agent tour and travel atau biro perjalan dirasa efektif karena mereka yang membawa wisatawan untuk 
melakukan kegiatan pariwisata. Kegiatan advertensi juga dapat dilakukan melalui imployment contcrat dengan influencer sebagai brand ambasador Desa Pasrujambe. Seorang influencer yang memiliki penggemar dan followers media sosial yang banyak dinilai mampu menginflunce atau memepengaruhi para penggemarnya untuk berkunjung dan berwisata di Desa Pasrujambe.

\section{Strategi ST (strengths - treaths)}

Adapun strategi yang dapat direncanakan dengan memaksimalkan kekuatan untuk mengahalangi ancaman-acaman yang ada di Desa Pasrujambe adalah sebagi berikut:

a. Mengelola dan optimalisasi salah satu potensi budaya Area Suci Watu Klosot sebagai salah satu iconic Desa Pasrujambe untuk meminimalisir terjadinya persaingan dengan 21 desa wisata yang berdiri di Kabupaten Lumajang, sehingga wisatawan tertarik untuk berkunjung karena memiliki produk wisata yang berbeda dengan rival desa wisata lainnya. Hal ini dapat dilakukan karena Area Suci watu Klosost memiliki nilai histrorical dan unsur magis sehingga menjadi originalitas tersendiri terlebih dengan adanya air suci yang memiliki unsur magis tersebut dipercaya dapat memberikan penyembuhan dan awet muda bagi wisatawan yang meminum dan membasuh muka menggunakan air suci tersebut. Hal tersebut dapat menjadi something to do bagi wisatawan yang menjadi pembeda saat mengunjungi Desa Wisata Pasrujambe dibandingkan desa wisata lainnya.

b. Optimalisasi potensi buatan seperti grebeg nusantara dan hasil olahan pertanian yang berguna sebagai ciri khas yang memiliki keunikan dan oringinalitas Desa Pasrujambe terhadap rival desa wisata lainnya di Kabupaten Lumajang. Ciri khas keunikan dan originalitas suatu produk wisata dirasa sangat penting untuk diciptakan agar menciptakan kesan the one and only bagi wisatawan yang berkunjung, karena mengingat peresmian desa wisata di Kabupaten Lumajang yang berjalan bersamaan.

c. Menciptakan sebuah image brand atau citra bagi Desa Pasurjambe agar menjadi pembeda dengan dengan 21 desa wisata lainnya. Hal ini dapat dilakukan dengan dilakukannya pembrandingan desa serta menciptakan sebuah tagline atau jargon yang dapat mengilustrasikan keseluruhan kondisi desa yang memiliki keunikan variasi potensi. Pembrandingan sebuah desa wisata perlu dilakukan agar selalu diingat dan menciptakan kesan memorable oleh wisatawan yang telah berkunjung ke desa tersebut.

d. Menjalin koordinasi berupa komunikasi secara intens dengan pihak keamanan di Kabupaten Lumajang dimulai dari sektor paling kecil yaitu sistem keamanan lingkungan desa, kepolisian sektor Kecamatan Pasrujambe hingga kepolisian resor Kabupaten Lumajang. Koordinasi ini perlu dilakukan mengingat citra Kabupaten Lumjang terhadap fenomena tindak kriminal khususnya begal dan sejenisnya sangat tidak baik. Oleh sebab itu komunikasi secara intens dan berkala harus tetap dilakukan guna menciptakan keamanan desa dan menumbuhkan rasa kepercayaan wisatawan terhadap keamanan dan kenyamaan saat melakukan kegiatan wisata di Desa Pasrujambe.

e. Mempererat hubungan koordinasi dan komunikasi secara baik dan rutin dengan BASARNAS Kabupaten Lumajang, dimana pihak tersebut merupakan pihak yang berkompeten terhadap penanggulangan fenomena bencana alam. Hubungan koordinasi dilakukan guna untuk menentukan titik kumpul saat terjadi bencana ataupun pelatihan-pelatihan simulasi terjadinya bencana alam di Desa Pasrujambe. Memahami rute titik kumpul menjadi penting untuk diketahui oleh masyarakat setempat sebagai penegatuhan dasar untuk memahami dan menguasai jalur evakuasi terhadap wisatawan yang berkunjung ke Desa Pasrujambe pada saat terjadi bencana alam. Selain itu, pihak BASARNAS memiliki peran sebagai pihak pertama yang dapat diminta bantuan dan dihubungi saat kondisi genting desa karena sedang terjadi fenomena musibah bencana alam.

\section{Strategi WT (weakness - treaths)}

Adapun strategi yang dapat dirumuskan dengan menekan kelemahan-kelamahan Desa Pasrujambe untuk mencegah anacaman yang muncul ada;ah sebagai berikut:

a. Mengoptimalkan pengetahuan secara umum dan khusus mengenai aktivitas kepariwisataan terhadap masyarakat lokal yang berkaitan dengan sikap pelayanan terhadap wisatawan, gestur tubuh maupun bahasa. Pengoptimalan tersebut dapat dilakukan dengan sosialisai oleh pihak yang berkompenten dibidangnya ataupun dengan pelatihan-pelatihan yang dapat meningkatkan skill masyarakat lokal. Hal ini perlu dilakukan, karena masyarakat Desa Pasrujambe merupakan host yang akan menyambut dan melayani wisatawan yang berkunjung dan melakukan aktivitas wisata.

b. Mengoptimalkan kinerja Pokdarwis Desa Pasrujambe sebagai garda depan pengelolaan aktivitas kepariwisataan didesanya. Pengoptimalan tersebut dapat dilakukan dengan melakukan study banding ke desa wisata yang memiliki implementasi kinerja yang sudah rapi dan terarah sehingga Pokdarwis dapat menambah wawasan yang lebih luas terhadap pengelolaan pariwisata dan dapat menyerap ilmu untuk diaplikasikan di Desa Pasrujambe dalam menjalankan kegiatan pariwisata didesanya. 
c. Melakukan FGD (forum grup discution) antara masayarakat, pokdarwis, dan pemeerintah desa ataupun daerah guna membahas keberlanjutan sebagai desa wisata. Menyaring dan menampung keinginan dari pihak stakeholders (masayarakat, pemerintah, dan investor) tersebut dapat dilakukan guna mencapai tujuan bersama sehingga tidak terjadi kesenjangan srtata sosial dalam menjalankan kegiatan pariwisata di Desa Pasrujambe.

\section{KESIMPULAN}

\section{A. Simpulan}

Berdasarkan hasil dan pembahasan dalam penilitian ini memiliki beberapa simpulan sebagai berikut:

1. Potensi-potensi yang dimiliki oleh Desa Pasrujambe dijabarkan menjadi tiga kategori yaitu potensi berbasis alam, budaya dan buatan. Kapasitas variasi potensi tersebut memiliki high opportunity untuk kegiatan ekspansi atau dikembangkan menjadi sebuah aktivitas wisata seperti something to do, something to see, dan something to buy yang dapat dinikmati wisatawan saat berkunjun. Selain itu variasi potensi tersebut memiliki nilai keunikan dan keoriginalitasan yang mempuni.

2. Mengidentifikasi segala peluang, tantangan, ancamam dan kekuatan yang dihadapi Desa Pasrujambe, kemudian di analisis menggunakan metode SWOT menghasilkan beberapa startegi yang terdiri dari startegi SO dengan lima startegi yang dirumuskan. Selanjutnya strategi WO dengan empat startegi yang berhasil dirumusakan. Selanjutnya strategi ST dengan empat stretegi yang berhasil dirumuskan. Strategi terkahir adalah strategi WT dengan tiga startegi yang berhasil dirumuskan. Strategi-strategi tersebut dirumuskan dengan tujuan untuk memaksimalkan dan optimalisasi keberadaan variasi potensi yang ada.

\section{B. Saran}

Adapun saran-saran yang mampu diberikan guna keberlangsungan pengembangan Desa Pasrujambe untuk beberapa pihak adalah.

1. Kepada pihak pemerintah khususnya pemerintah daerah Kabupaten Lumajang agar lebih melakukan kegiatan controling terhadap kondisi perkembangan dan pengembangan desa-desa wisata yang telah ditetapkan sebagai destinasi wisata di Kabupaten Lumajang, terlebih Desa Pasrujambe. Hal ini untuk mencegah ajang pelabelan semata sebuah desa wisata namun tidak memiliki kegitan kepariwisataaan yang sesungguhnya. Pihak pemerintah Daerah Kabupaten Lumajang dan Pemerintah Desa Pasrujambe hendaknya bersinergi mengenai anggaran dana sebagai desa wisata. Dimana desa ini tidak memiliki anggaran khusus untuk kegiatan peningkatan, pembaharuan, dan pengadaan amenitas ataupun aksesbilitas sebagai desa wisata serta hanya memanfaatkan dana swadaya dari masyarakat lokal, sehingga Desa Pasrujambe masih tergolong sulit untuk melakukan kegiatan optimalisasi dan pengembangan potensi yang ada. Pihak Pemerintah Desa Pasrujambe hendaknya memberikan sosialisasi dasar terhadap masyarakat mengenai variasi potensi dan kegiatan wisata yang akan dilakukan di desa tersebut, sehingga nantinya masyarakat mempunyai atensi yang lebih terhadap kegiatan pariwisata di desanya. Hal ini dapat dilakukan dengan melibatkan masayarakat dalam planning dan pelaksanaan sehingga masyarakat memiliki partisiapasi yang sama rata dalam implementasi sebagai desa wisata.

2. Kelompok Sadar Wisata (Pokdarwis) Desa Pasrujambe sebagai garda pertama yang melaksanakan kegiatan wisata di Desa Pasrujambe harus meningkatkan kualitas kerja. Peningkatan kualitas kerja dapat diciptakan dengan menyusun jobdesk yang jelas bagi setiap seksi serta mencipatakan target pencapaian atau goals, dengan jobdesk kinerja pokdarwis akan semakin terarah dan tetap on target. Selain itu untuk mencegah terjadinya jarak dan kesenjangan anatra pokdarwis dengan masyarakat lokal maka diperlukan perlibatan masyarakat dalam kegiatan pariwisata dan transparansi hasil pemasukan hasil wisata mengingat potensi yang digunakan merupakan milik masyarakat Desa Pasrujambe sepenuhnya.

3. Bagi masyarakat Desa Pasrujambe untuk meningkatkan rasa peduli dan memiliki terhadap keberadaan variasi potensi desanya sehingga dapat menjaga dan melestarikan keberadaannya. Selain itu masayarakat harus lebih meningkatkan rasa atensi terhadap kegiatan kepariwisataan terlebih desanya terlah dirujuk sebagai desa wisata dan memiliki SK secara resmi yang diberikan pemerintah daerah.

\section{DAFTAR PUSTAKA}

Fitriani, Hanifa. 2014. Strategi Pengembangan Desa Wisata Talun Melalui Model Pemberdayaan Masyarakat. Econimic Develompment Analysis Journal 3(1).

Koenjaraningrat. 1997. Metode-Metode Penelitian Ilmu Sosial. Jakarta: Rajawali.

Mahagangga, I. G. A. O., Sos, S., Anom, I. P., Par, M., \& Suryasih, I. A KAJIAN PENGEMBANGAN DESA WISATA DI KABUPATEN BADUNG. Google Scholar Link.

Narottama, Nararya. 2016. The Implementations of Cultural BasedHolostic Managements Concept to Minimized The Negative Impacts of Tourism (Case Study: Coastal Area of Sanur, Bali). Jurnal Atlantis Pers.

Pendit, Nyoman S. 1999. Ilmu PariwisataSebuah PengantarPerdana. Jakarta: PradyaParamita.

Rangkuti, Freddy. 2015. Analisis SW0T Teknik MembedahKasus Bisnis. Jakarta: PT. Grammedia Pustaka Utama. 
Sunarta, I Nyoman \& Nyoman Sukma Arida. 2017. Buku Pariwisata Berkelanjutan. Denpasar: Cakra Press.

Suryawan, I. B., \& Mahagangga, I. G. A. O. (2017). Penelitian Lapangan 1.Denpasar: Cakra Media dan Fakultas Pariwisata Universitas Udayana.

Yoeti, A. Oka. 2008. Perencanaan dan Pengembangaan Parwisata Jakarta: Pradnya Paramita.
Sumber lainnya:

Dewipesir. 2017. Desa Wisata Pasrujambe. Diakses pada tanggal 25 Maret 2019. http://dewipasir.blogspot.com/

Dinas Pariwisata \& Kebudayan Kab. Lumajang. 2019. Profil Pariwisata Kab. Lumajang. Diakses Pada tanggal 26 Maret 2019. https://disparbud.lumajangkab.go.id. 